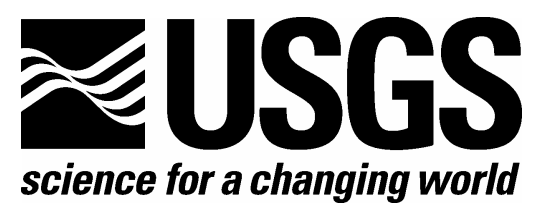

\title{
Deposition, Erosion, and Bathymetric Change in South San Francisco Bay: 1858-1983
}

By Amy C. Foxgrover ${ }^{1}$, Shawn A. Higgins ${ }^{1}$, Melissa K. Ingraca ${ }^{1}$, Bruce E. Jaffe ${ }^{1}$, and Richard E. Smith ${ }^{2}$

${ }^{1}$ US Geological Survey Pacific Science Center, Santa Cruz, CA

${ }^{2}$ US Geological Survey Water Resources Division, Menlo Park, CA

Any use of trade, firm, or product names is for descriptive purposes only and does not imply endorsement by the U.S. Government

Open-File Report 2004-1192

2004

U.S. Department of the Interior U.S. Geological Survey 


\section{U.S. Department of the Interior \\ Gale A. Norton, Secretary}

\section{U.S. Geological Survey}

Charles G. Groat, Director

U.S. Geological Survey, Reston, Virginia 2004

For product and ordering information:

World Wide Web: http://www.usgs.gov/pubprod

Telephone: 1-888-ASK-USGS

For more information on the USGS-the Federal source for science about the Earth, its natural and living resources, natural hazards, and the environment:

World Wide Web: http://www.usgs.gov

Telephone: 1-888-ASK-USGS

Although this report is in the public domain, permission must be secured from the individual copyright owners to reproduce any copyrighted material contained within this report. 


\section{Table of Contents}

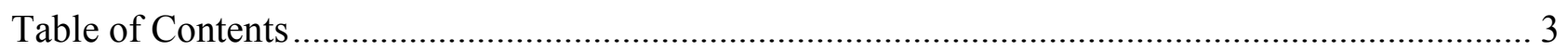

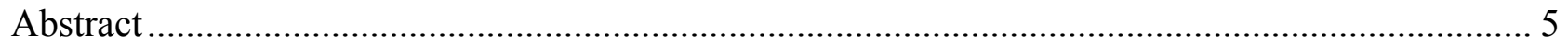

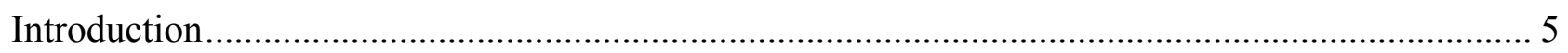

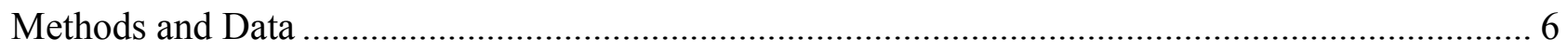

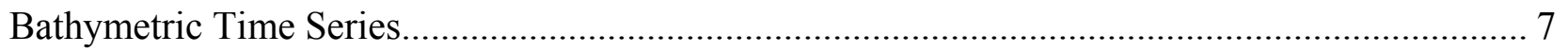

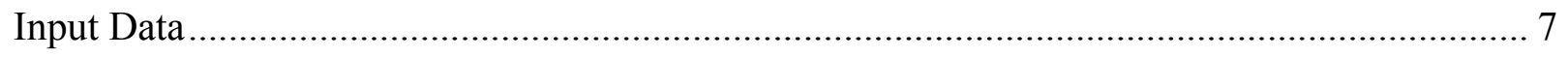

$1850 \mathrm{~s}$

$1890 \mathrm{~s}$

$1930 \mathrm{~s}$

$1950 \mathrm{~s}$

$1980 \mathrm{~s}$

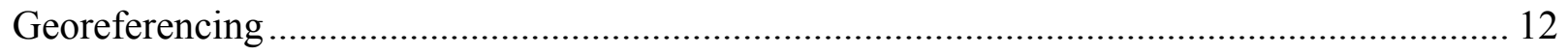

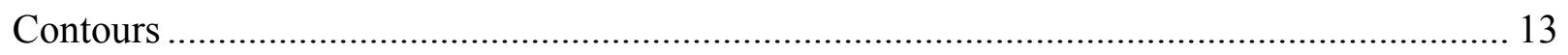

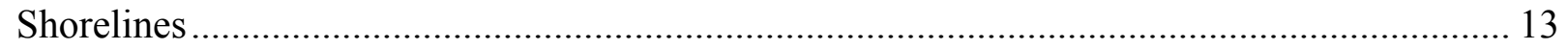

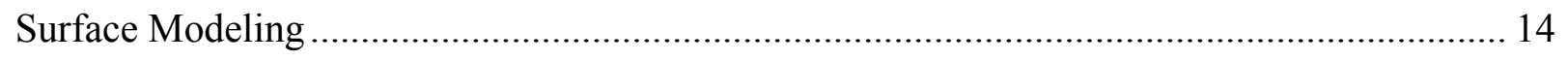

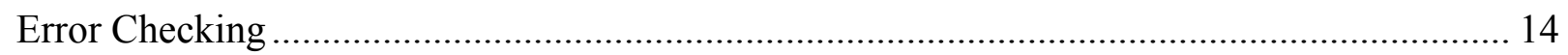

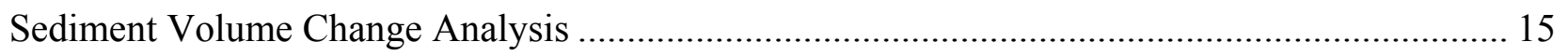

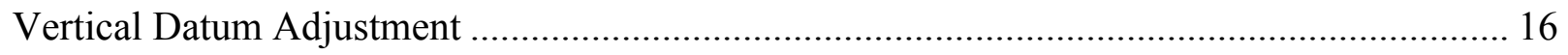

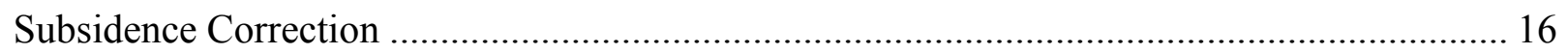

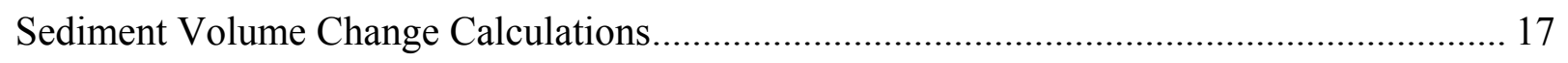

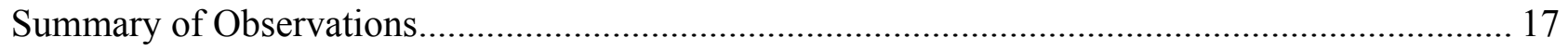

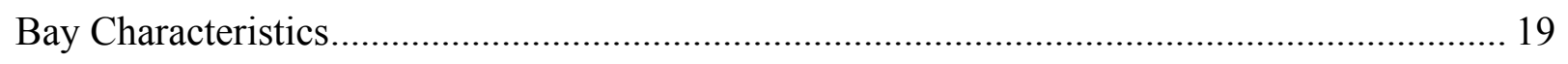




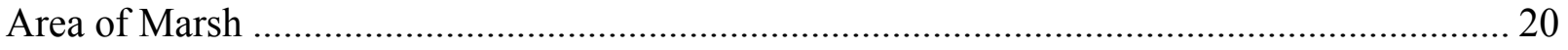

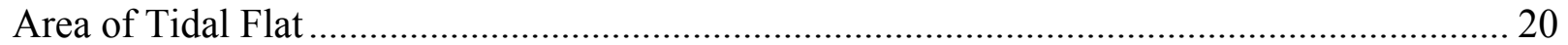

Net Sediment Volume Change .............................................................................. 21

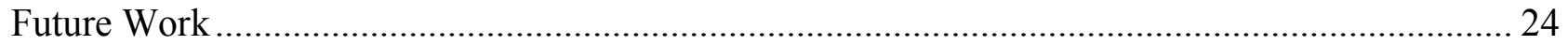

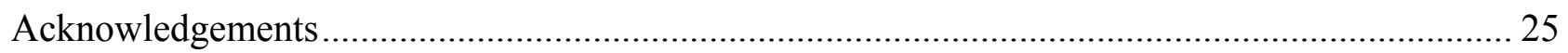

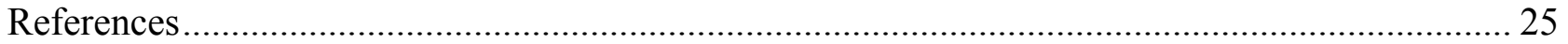




\title{
Deposition, Erosion, and Bathymetric Change in South San Francisco Bay: 1858 - 1983
}

\author{
By Amy C. Foxgrover ${ }^{1}$, Shawn A. Higgins ${ }^{1}$, Melissa K. Ingraca ${ }^{1}$, Bruce E. Jaffe ${ }^{1}$, and \\ Richard E. Smith ${ }^{2}$ \\ ${ }^{1}$ US Geological Survey Pacific Science Center, Santa Cruz, CA \\ ${ }^{2}$ US Geological Survey Water Resources Division, Menlo Park, CA
}

\section{Abstract}

Since the California Gold Rush of 1849, sediment deposition, erosion, and the bathymetry of South San Francisco Bay have been altered by both natural processes and human activities. Historical hydrographic surveys can be used to assess how this system has evolved over the past 150 years. The National Ocean Service (NOS) (formerly the United States Coast and Geodetic Survey (USCGS), collected five hydrographic surveys of South San Francisco Bay from 1858 to 1983. Analysis of these surveys enables us to reconstruct the surface of the bay floor for each time period and quantify spatial and temporal changes in deposition, erosion, and bathymetry.

The creation of accurate bathymetric models involves many steps. Sounding data was obtained from the original USCGS and NOS hydrographic sheets and were supplemented with hand drawn depth contours. Shorelines and marsh areas were obtained from topographic sheets. The digitized soundings and shorelines were entered into a Geographic Information System (GIS), and georeferenced to a common horizontal datum. Using surface modeling software, bathymetric grids with a horizontal resolution of $50 \mathrm{~m}$ were developed for each of the five hydrographic surveys. Prior to conducting analyses of sediment deposition and erosion, we converted all of the grids to a common vertical datum and made adjustments to correct for land subsidence that occurred from 1934 to 1967. Deposition and erosion that occurred during consecutive periods was then computed by differencing the corrected grids. From these maps of deposition and erosion, we calculated volumes and rates of net sediment change in the bay.

South San Francisco Bay has lost approximately $90 \times 10^{6} \mathrm{~m}^{3}$ of sediment from 1858 to 1983; however within this timeframe there have been periods of both deposition and erosion. During the most recent period, from 1956 to 1983, sediment loss approached $3 \times 10^{6} \mathrm{~m}^{3} / \mathrm{yr}$. One of the most striking changes that occurred from 1858 to 1983 was the conversion of more than $80 \%$ of the tidal marsh to salt ponds, agricultural, and urban areas. In addition, there has been a decline of approximately $40 \%$ in intertidal mud flat area. Restoration of these features will require a detailed understanding of the morphology and sediment sources of this complex system.

\section{Introduction}

San Francisco Bay is centrally located along the California coast where the Sacramento and San Joaquin Rivers join to form the West Coast's largest estuary (Fig. 1). At the time that the first hydrographic survey was collected in South San Francisco Bay (1858), there were approximately 100,000 people living in the San Francisco Bay area; today it is home to nearly seven million. This rapid increase in population has placed a number of pressures upon the estuary. In addition to 
natural processes such as sea-level rise, climatic influences on sediment delivery, and wind wave erosion, anthropogenic influences have altered patterns of sediment deposition and erosion throughout the estuary. Changes in bathymetry from 1858 to 1983 were documented by a series of hydrographic surveys. Utilizing Geographic Information Systems (GIS), we were able to conduct detailed analyses of these historical hydrographic surveys to assess not only spatial and temporal trends, but to quantify changes in net sediment volumes and rates over greater than decadal time scales.

This study is the third in a series that documents historical bathymetric change and the deposition and erosion of sediment in San Francisco Bay (Jaffe et al., 1998; Cappiella et al., 1999; United States Geological Survey San Francisco Bay Bathymetry Web Site). The study area for this report is South San Francisco Bay, which has been defined as the area South of Hunter's Point (Fig. 1). The National Ocean Service (NOS) (formerly the United States Coast and Geodetic Survey (USCGS) collected five hydrographic surveys of South San Francisco Bay from 1858 to 1983 which serve as the basis for our models.

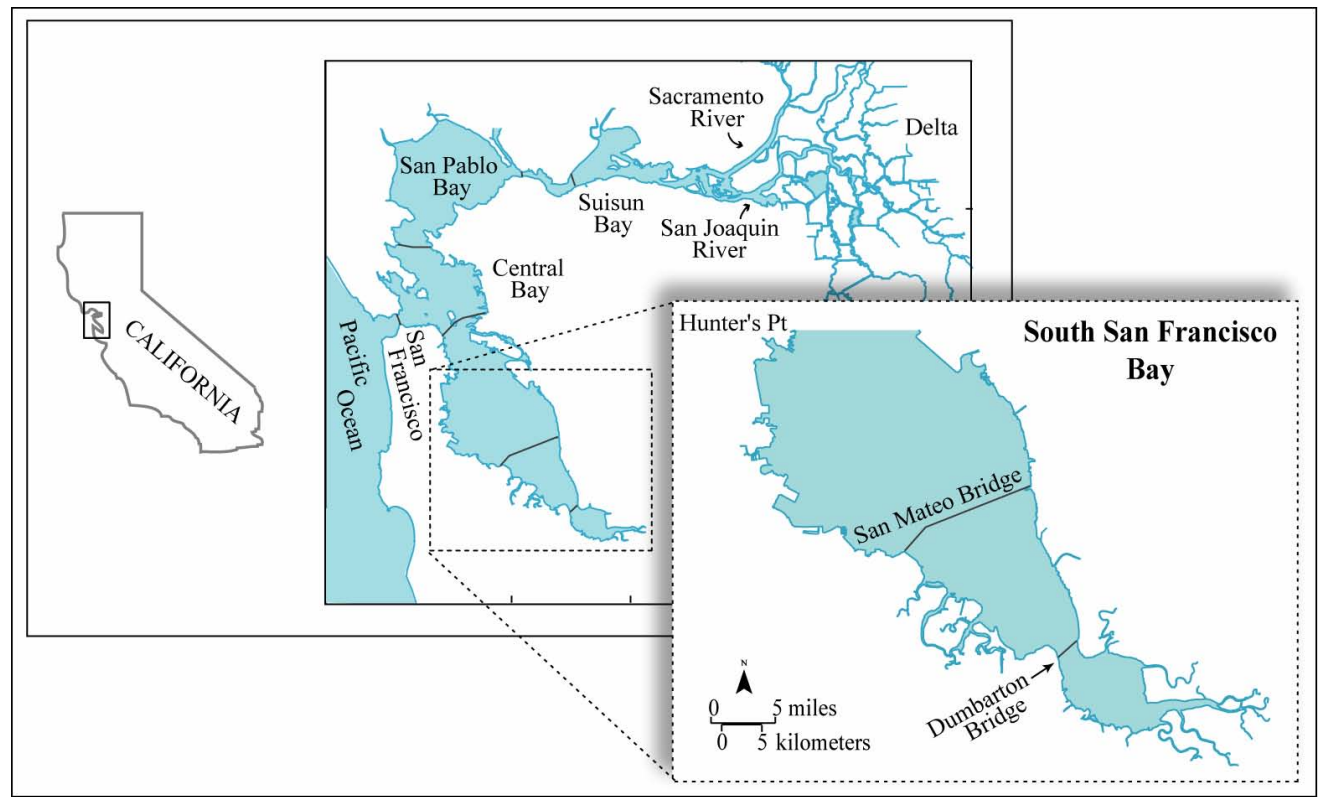

Figure 1. Location of study area.

Compiling these data into a GIS was especially time consuming. Over 300,000 soundings, associated contours, and shorelines were analyzed to produce the bathymetric surfaces. However, analyses of long-term trends in the deposition and erosion of sediment provide insight into a dynamic system that is difficult to gain with short-term field studies. Using this data, we are able to investigate how the documented changes in bathymetry relate to changing biological communities, contaminant issues, and future development within this estuary.

\section{Methods and Data}

Bathymetric soundings were obtained from the original USCGS and NOS hydrographic sheets (H-sheets) (Fig. 2). Bathymetric contours were digitized either from the H-sheets directly or based upon sounding values. Supplementary contours were manually added to the 1850's tidal flats where the original sounding values have been omitted from the H-sheets. An additional contour was added to all of the surveys, parallel to the shoreline, $20 \mathrm{~m}$ within the bay, to ensure realistic nearshore morphology in areas where soundings were not available (see contour section). Shoreline and marsh data were taken from topographic sheets (T-sheets). Once all of the 
information was converted into a digital format, it was georeferenced, or assigned real world coordinates, and combined into a GIS. Continuous surface representations (bathymetric grids) with a horizontal resolution of $50 \mathrm{~m}$ were generated for each of the five hydrographic surveys using ArcInfo's TopoGrid module. TopoGrid is a modeling algorithm specifically designed to utilize both point and contour data to retain proper hydrogeomorphic properties. To ensure high-quality bathymetric grids, error checking techniques were applied at various stages of data processing.

Prior to conducting analyses of sediment deposition and erosion, we converted all of the grids to a common vertical datum to account for changes in sea level over the 125-year span of the surveys. In addition, we made adjustments to correct for land subsidence that occurred in the Santa Clara Valley from 1934 to 1967. Deposition and erosion that occurred within consecutive periods was then computed by differencing the corrected grids. The amount of sediment eroded and deposited between periods was calculated on a cell by cell basis to quantify net sediment volume change and rates of change throughout the bay.

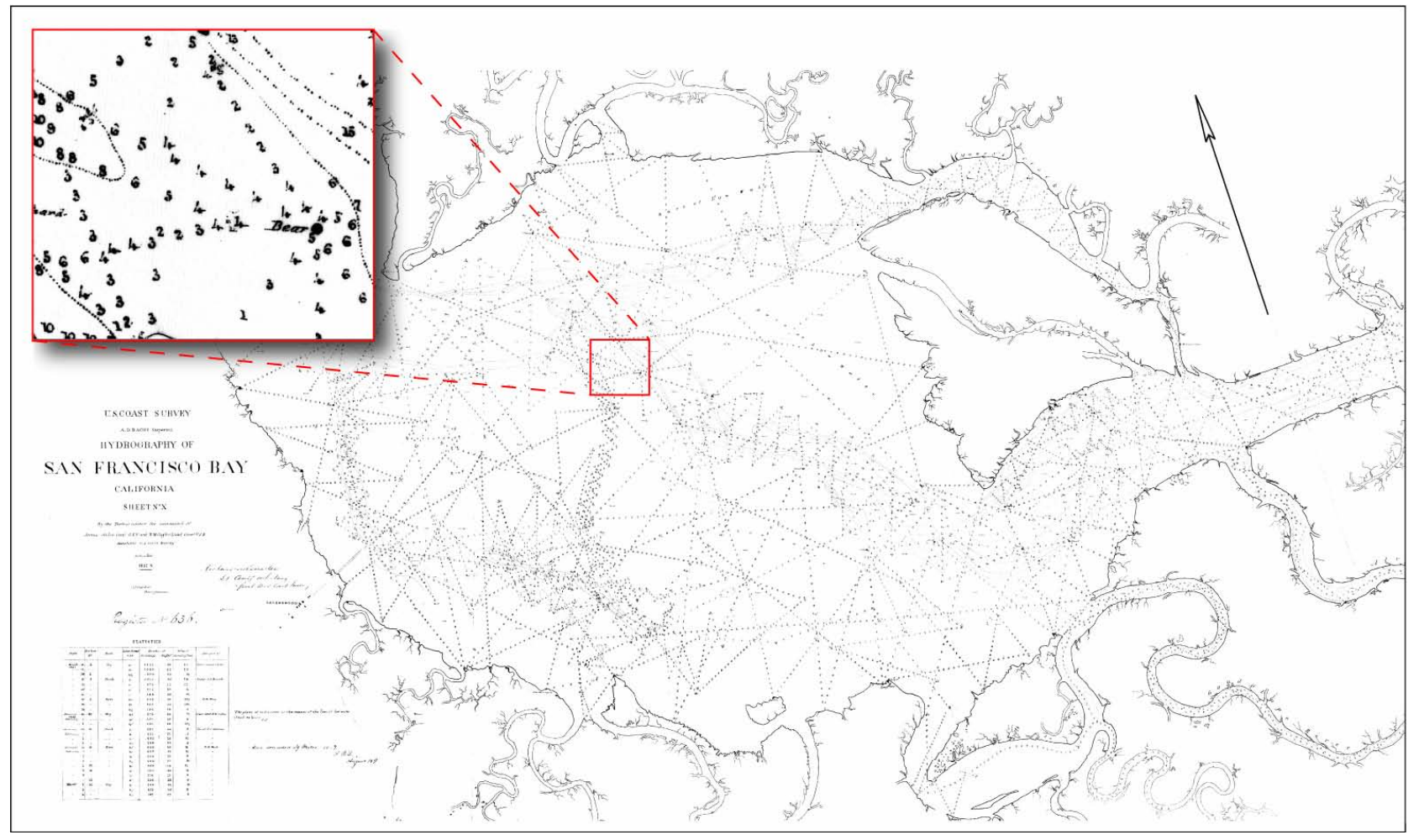

Figure 2. Example of a historical $1858 \mathrm{H}$-sheet. The data distribution is typical of the 1850's hydrographic surveys.

\section{Bathymetric Time Series}

\section{Input Data}

1850s

Soundings for the 1850's surveys were manually digitized from scanned images of H-sheets obtained from the Hydrographic Surveys Division of the NOS (Table 1). Hand-drawn depth contours were digitized based upon $\mathrm{H}$-sheet data and supplemented manually as needed to maintain a consistent contour interval throughout all of the surveys (Fig. 3). The shorelines, as well as the 
marsh boundaries for the 1850's surveys, were obtained digitally from the San Francsico Estuary Institute's (SFEI) EcoAtlas (1998).

It was common practice on the earliest $\mathrm{H}$-sheets for all soundings above Mean Lower Low Water (MLLW) to be assigned a blanket value of zero (Dedrick, 1983). This was a result of USCGS plotting standards at that time and does not accurately reflect the slope of the tidal flats. To create a more realistic slope, we artificially generated contours at approximately $1 / 2$ and $1 / 4$ of the distance between the shoreline, represented by Mean High Water (MHW), and MLLW. These contours were assigned values of $25 \%$ and $50 \%$, respectively; of Mean Tide Level (MTL) elevations (see contours section). All zero soundings between MLLW and MHW were removed from the gridding routine. This is a rough estimate of tidal flat slope based upon 1898 surveys in which soundings above MLLW were retained. Kent Dedrick and others with the CA State Lands Commission have replaced the zero values above MLLW with the reduced soundings derived from the original USCGS tidal observation books. It is our hope to incorporate these values into our work in the near future.

Due to the relatively sparse distribution of data in the 1850's surveys, it was necessary to add a limited number of supplementary soundings (based upon surrounding values) to narrow channels crossing the tidal flats in order to maintain channel connectivity through the mudflat.

Table 1. Table of 1850's H-sheets of South San Francisco Bay.

\begin{tabular}{||l|l|l|l||}
\hline \multicolumn{1}{|c|}{ H-Sheet } & \multicolumn{1}{c|}{ Year } & \multicolumn{1}{c|}{ Scale } & \multicolumn{1}{c|}{ Soundings } \\
\hline \multicolumn{4}{|c|}{} \\
\hline H628 & $1857-58$ & $1: 20,000$ & 9,898 \\
\hline H629 & $1857-58$ & $1: 10,000$ & 2,250 \\
\hline H636 & $1857-58$ & $1: 10,000$ & 6,373 \\
\hline H637 & 1858 & $1: 10,000$ & 1,003 \\
\hline H638 & 1858 & $1: 10,000$ & 512 \\
\hline & & & Total $=20,036$ \\
\hline
\end{tabular}
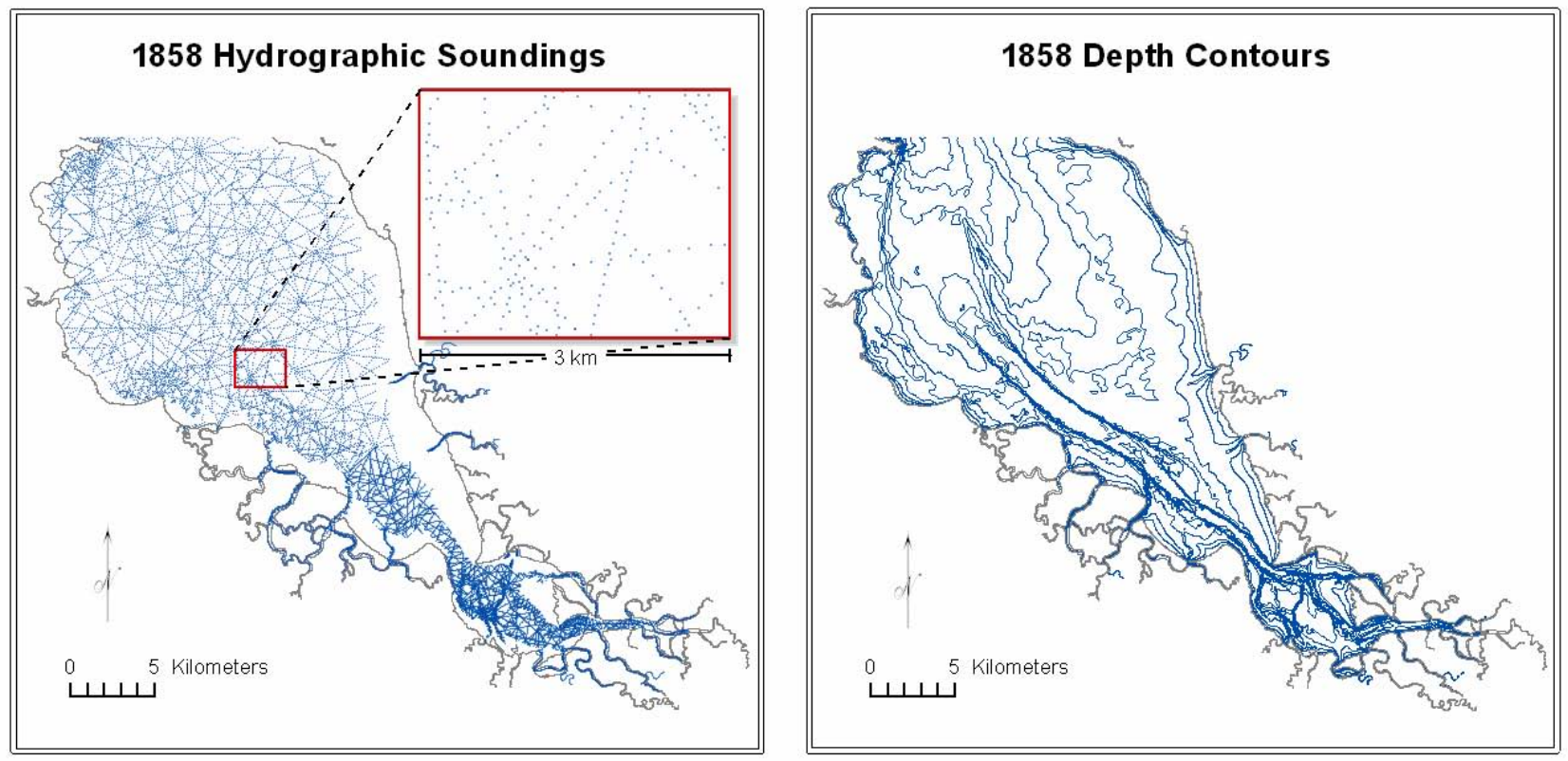

Figure 3. 1850's soundings and contours used for surface modeling. 
Soundings for the 1890's surveys were manually digitized from scanned images of H-sheets obtained from the Hydrographic Surveys Division of the NOS (Table 2). Hand-drawn depth contours were digitized based upon $\mathrm{H}$-sheet data and supplemented manually as needed to maintain a consistent contour interval throughout all of the surveys (Fig. 4). The shorelines and the marsh boundaries were digitized from scanned images of Topographic-sheets (T-sheets).

Table 2. Table of 1890's H-sheets of South San Francisco Bay.

\begin{tabular}{||l|l|l|l||}
\hline \multicolumn{1}{||c|}{ H-Sheet } & \multicolumn{1}{c|}{ Year } & \multicolumn{1}{c||}{ Scale } & \multicolumn{1}{c||}{ Soundings } \\
\hline \multicolumn{4}{|l|l||}{} \\
\hline H2304 & 1897 & $1: 20,000$ & 10,839 \\
\hline H2315 & 1897 & $1: 20,000$ & 34,321 \\
\hline H2411 & $1898-99$ & $1: 20,000$ & 16,206 \\
\hline H2412 & 1898 & $1: 10,000$ & 15,803 \\
\hline H2413 & 1898 & $1: 10,000$ & 5,418 \\
\hline H2414 & 1898 & $1: 10,000$ & 2,982 \\
\hline H2415 & 1898 & $1: 10,000$ & 13,830 \\
\hline & & & Total $=99,399$ \\
\hline
\end{tabular}
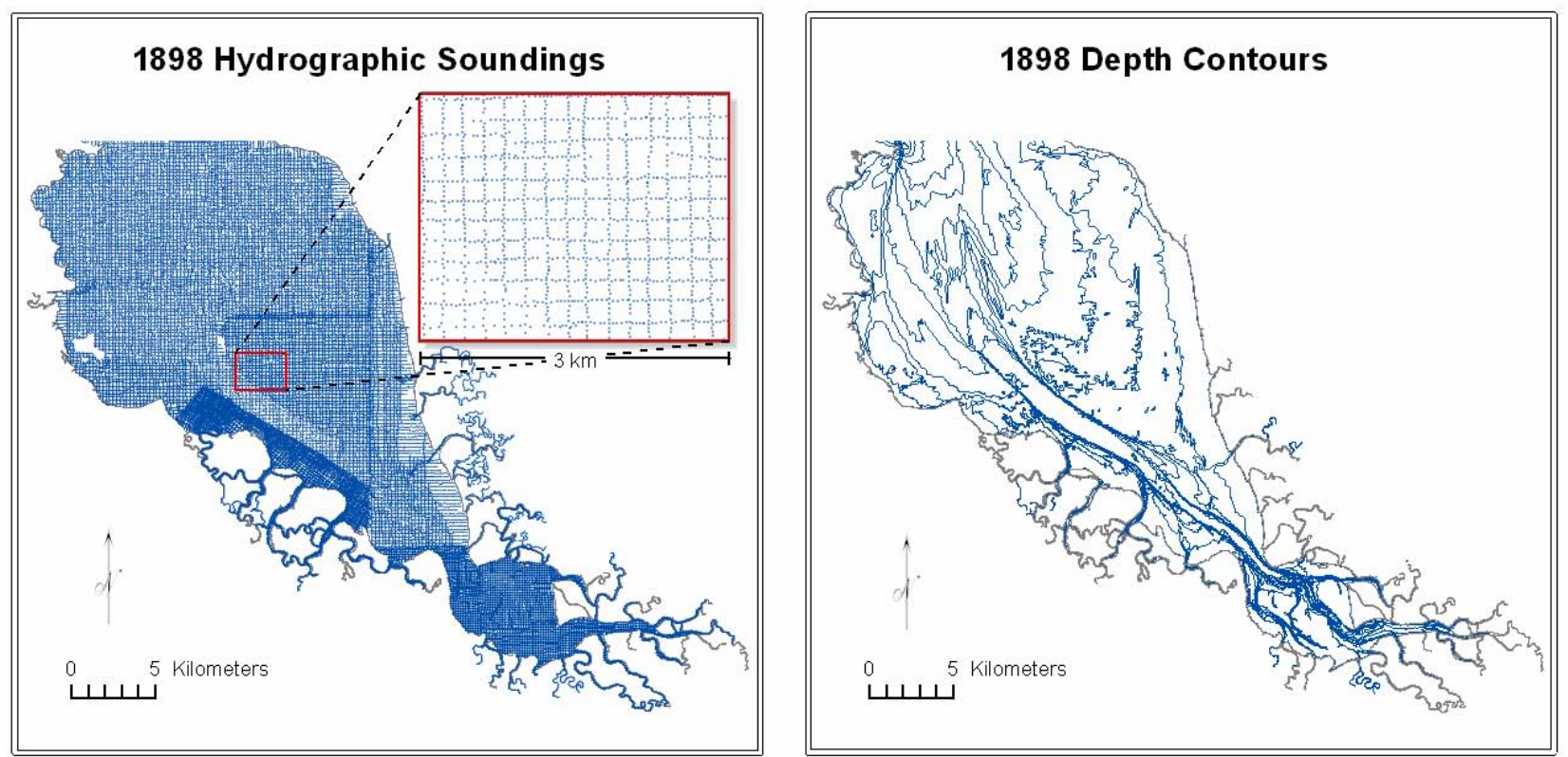

Figure 4. 1890's soundings and contours used for surface modeling.

1930s

The majority of the 1930's depth soundings were obtained digitally from the National Geophysical Data Center's (NCDC) GEOphysical Data System (GEODAS) (1996) with the exception of H4137. Soundings from H4137 were manually digitized from a scanned image of the H-sheet obtained from the Hydrographic Surveys Division of the NOS (Table 3). Hand-drawn depth contours were digitized based upon depth soundings (Fig. 5). The shorelines for the 1931 surveys were obtained digitally from the National Geodetic Survey (NGS) NOAA Shoreline Data Explorer. The marsh extent was digitized from georeferenced, scanned images of T-sheets obtained from the NOAA National Ocean Service Coastal Services Center.

Although we label our bathymetric maps with a single year, hydrographic surveys customarily are conducted over the span of a few years. The year displayed on our maps is the year in which the majority of the surveys were conducted. There was an exceptional time lapse of 
approximately ten years within the 1931 survey. The northernmost survey within the study area (H4137) was surveyed in 1919-20 while the remaining surveys were collected in 1931. There was a slight area of overlap between the H4137 (1919-20) and H5129 (1931) in the vicinity of San Bruno Shoal that indicated differences of one to three feet between sounding values. We did not feel justified in performing linear interpolations in an attempt to bring the data to a common date and rather decided to honor the original data. Overlapping soundings between the two time periods were removed, and rates of sediment volume change were calculated using separate regions to account for this disparity in time periods.

Table 3. Table of 1930's H-sheets of South San Francisco Bay.

\begin{tabular}{|c|c|c|c|}
\hline H-Sheet & Year & Scale & Soundings \\
\hline H4137 & 1919-20 & $1: 20,000$ & 23,509 \\
\hline H5129 & 1931 & $1: 20,000$ & 25,185 \\
\hline H5131 & 1931 & $1: 10,000$ & 10,313 \\
\hline H5133 & 1931 & $1: 10,000$ & 12,276 \\
\hline H5135 & 1931 & $1: 10,000$ & 8,409 \\
\hline H5139 & 1931 & $1: 10,000$ & 7,735 \\
\hline H5140 & 1931 & $1: 10,000$ & 5,024 \\
\hline & & & Total $=92,451$ \\
\hline
\end{tabular}
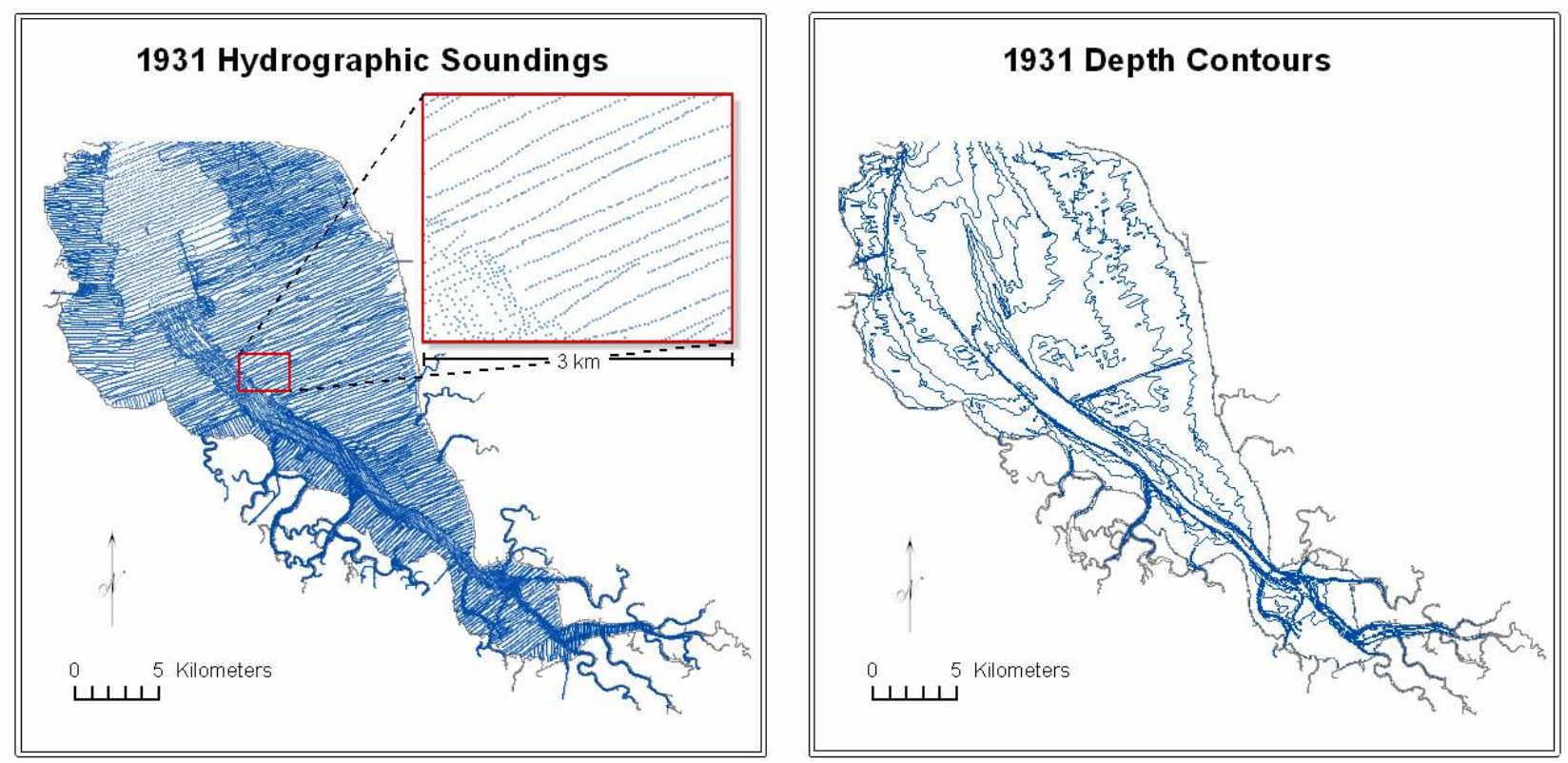

Figure 5. 1930's soundings and contours used for surface modeling.

1950s

Depth soundings for the 1950's surveys were obtained digitally from NGDC's GEODAS database (1996) (Table 4). Hand-drawn depth contours were digitized based upon H-sheet data and supplemented manually as needed to maintain a consistent contour interval throughout all of the surveys (Fig. 6). The shorelines for the 1950's surveys were digitized from H-sheets. The marsh boundaries were digitized from scanned, georeferenced images of T-sheets obtained from the NOAA National Ocean Service Coastal Services Center.

GEODAS soundings for H8025 (near Hunter's Point) were missing some soundings that existed on the original H-sheet; these soundings were manually digitized. 
Table 4. Table of 1950's H-sheets of South San Francisco Bay.

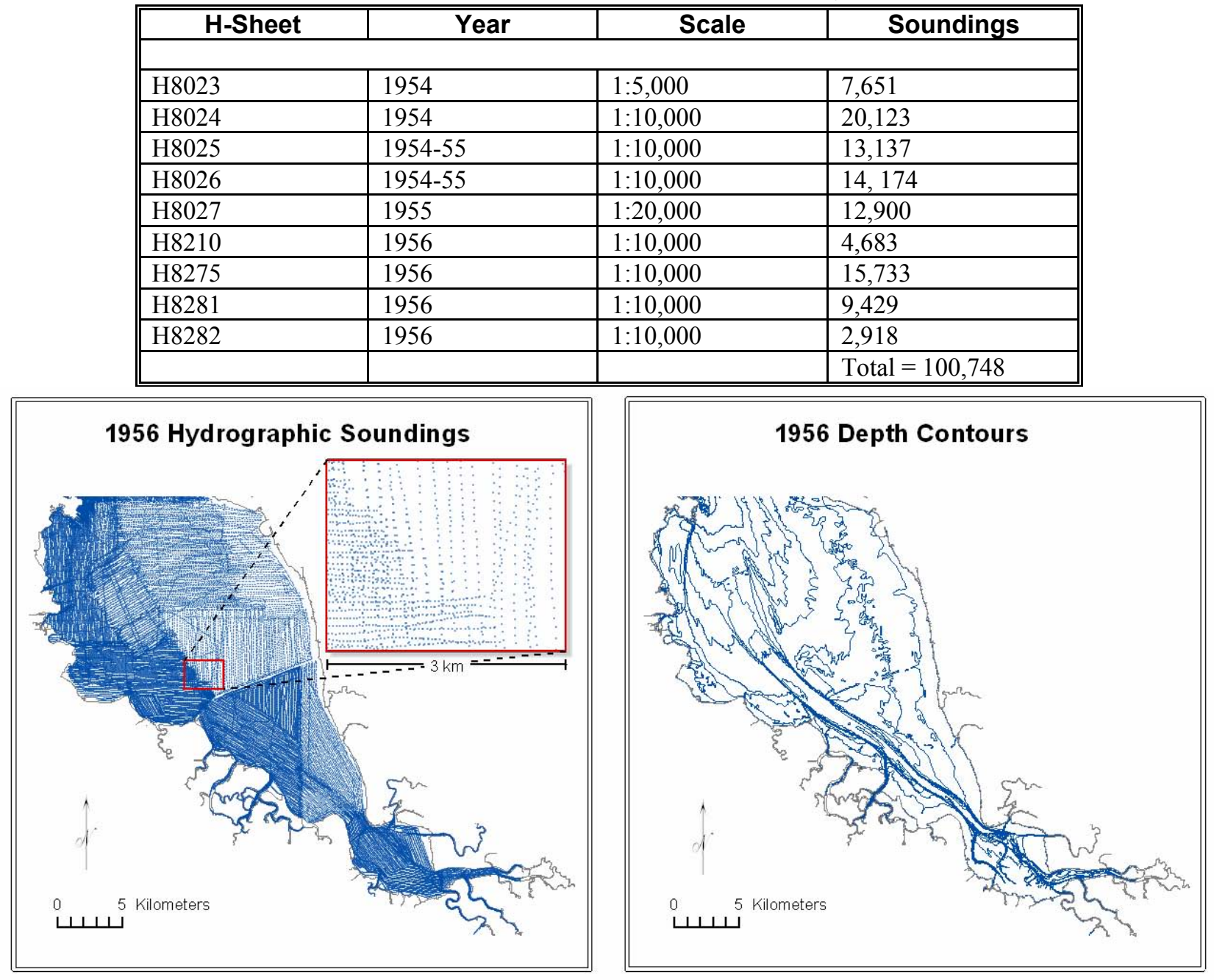

Figure 6. 1950's soundings and contours used for surface modeling.

1980s

Digital soundings for the 1980's surveys were obtained from NGDC's GEODAS database (1996) (Table 4). Hand-drawn depth contours were digitized based upon depth soundings (Fig. 7). The shorelines as well as the marsh boundaries were obtained digitally from SFEI's EcoAtlas (1998).

It was discovered that select soundings from H10132 (downloaded from GEODAS) were apparently assigned an incorrect depth code. Soundings above MLLW (intertidal soundings) appeared to be recorded in centimeters rather than decimeters. These points were selected and converted from centimeters to decimeters to match the rest of the data. There was an additional cluster of approximately 30 soundings within H10102 located near Redwood Creek whose values differed from their surrounding soundings by over an order of magnitude. No logical correction was evident, so these points were removed. 
Table 5. Table of 1980's H-sheets of South San Francisco Bay.

\begin{tabular}{||l|l|l|l||}
\hline \multicolumn{1}{|c|}{ H-Sheet } & \multicolumn{1}{c|}{ Year } & \multicolumn{1}{c||}{ Scale } & \multicolumn{1}{c||}{ Soundings } \\
\hline H9819 & 1979 & $1: 5,000$ & 19,645 \\
\hline H10102 & $1983-84$ & $1: 100,000 ?$ & 12,600 \\
\hline H10158 & $1984-85$ & $1: 10,000$ & 5,819 \\
\hline H9869 & 1980 & $1: 10,000$ & 12,726 \\
\hline H9872 & 1980 & $1: 20,000$ & 21,356 \\
\hline H9952 & $1981-82$ & $1: 10,000$ & 22,439 \\
\hline H9984 & $1981-83$ & $1: 10,000$ & 11,413 \\
\hline H10070 & $1982-83$ & $1: 10,000$ & 12,227 \\
\hline H10132 & $1984-85$ & $1: 10,000$ & 17,870 \\
\hline & \multicolumn{3}{l}{} \\
\hline
\end{tabular}
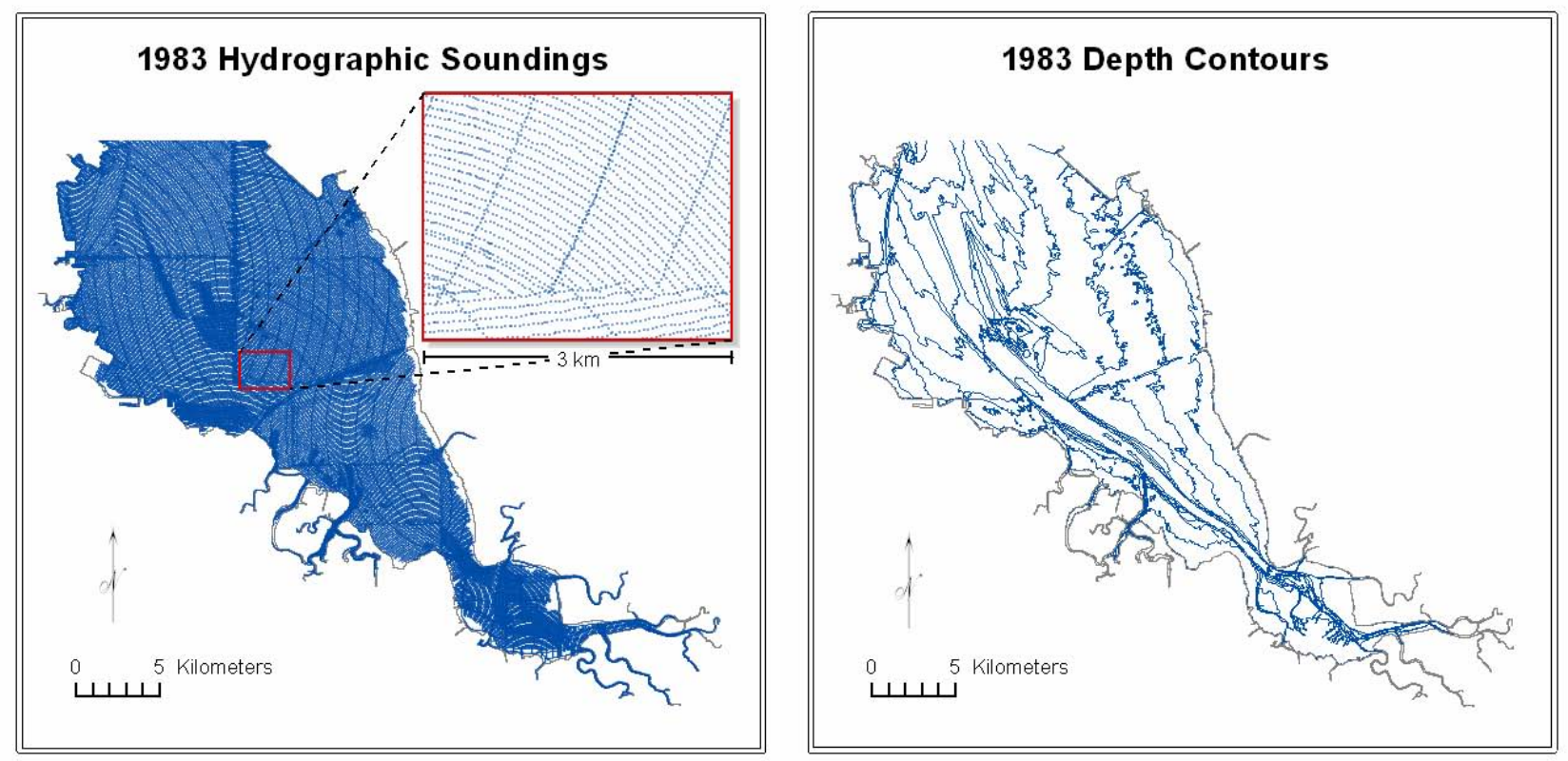

Figure 7. 1980's soundings and contours used for surface modeling.

\section{Georeferencing}

Georeferencing the early surveys was especially challenging because the 1850's hydrographic sheets contained no discernable coordinate information. The H-sheets were georeferenced using common shoreline features with SFEI's shoreline coverage. For each H-sheet several control points were placed along distinct shoreline features on the $\mathrm{H}$-sheet that were also observable on the SFEI shoreline coverage. Coordinate information from the SFEI coverage was assigned to the control points and a best-fit transformation was performed to minimize error over the entire sheet.

The 1890's H-sheet and T-sheets contain graticules depicting longitude and latitude referenced to a localized datum. To determine the relationship of this local datum to the established North American Datum 1927 (NAD27), the sheets were registered using published coordinate values of four triangulation stations throughout the bay (Mitchell, 1936). Based upon 
these coordinates a standard correction shift was calculated and applied to the graticule values on the published H-sheets and T-sheets.

Hydrographic data from the 1930's surveys were referenced to an earlier U.S. Standard Datum (soundings downloaded from the GEODAS database appeared to be incorrectly registered). We received the 1931 shoreline coverage and digital images of the corresponding topographic surveys from the NOAA National Ocean Service Coastal Services Center; georeferenced to UTM NAD83. Coordinate values from triangulation stations on the T-sheets were used to georeference the H-sheets. The digital GEODAS soundings were then adjusted to agree with the properly registered $\mathrm{H}$-sheet.

H-sheets and T-sheets from the 1950's and 1980's surveys were properly referenced to NAD27 on the original maps.

\section{Contours}

Depth contours assist in defining the general morphology of the bathymetric grids and stabilize the model in areas of sparse soundings. Contours were digitized from H-sheets at MLLW, $3,6,12,18,24,30,36,50,60,70$, and $80 \mathrm{ft}$. Depth contours for surveys prior to 1930 , and for the 1950 's surveys were digitized from H-sheets and supplemented as needed to maintain a consistent contour interval throughout all of the surveys. Depth contours for the 1930's and 1980's surveys were added manually based upon sounding values. In general, depth contours were only drawn in areas supported by a minimum of three soundings.

In many areas there are gaps in excess of $150 \mathrm{~m}$ between the shallowest soundings and the shoreline. In order to best model the steep slope of the mudflat as it approaches the shoreline in areas where soundings do not exist within the first grid cell (50 m from shore) an additional contour has been placed parallel to the shoreline at a distance of $20 \mathrm{~m}$ within the bay and assigned an approximate value of MTL. The MTL values were derived from various tidal stations around the perimeter of the bay and interpolated between stations to assign a continuous elevation value to the shoreline buffer. This provides a means of modeling the steep slope of the nearshore morphology within the confines of a $50 \mathrm{~m}$ grid cell and may not be an accurate reflection of nearshore morphology.

\section{Shorelines}

All of the shorelines used for this study were originally derived from T-sheets, and are defined as the MHW line. For modeling purposes it was necessary to assign an elevation to this boundary. Due to the large tidal range of South San Francisco Bay, MHW values vary significantly from north to south. In order to reflect this variation, MHW values were derived from various tidal stations around the perimeter of the bay and interpolated between stations to assign continuous elevation values to the shorelines (Fig. 8). It is important to note that while this assignment of shoreline elevations is sufficient for our modeling purposes, it is not intended to provide specific MHW values at any given location. 


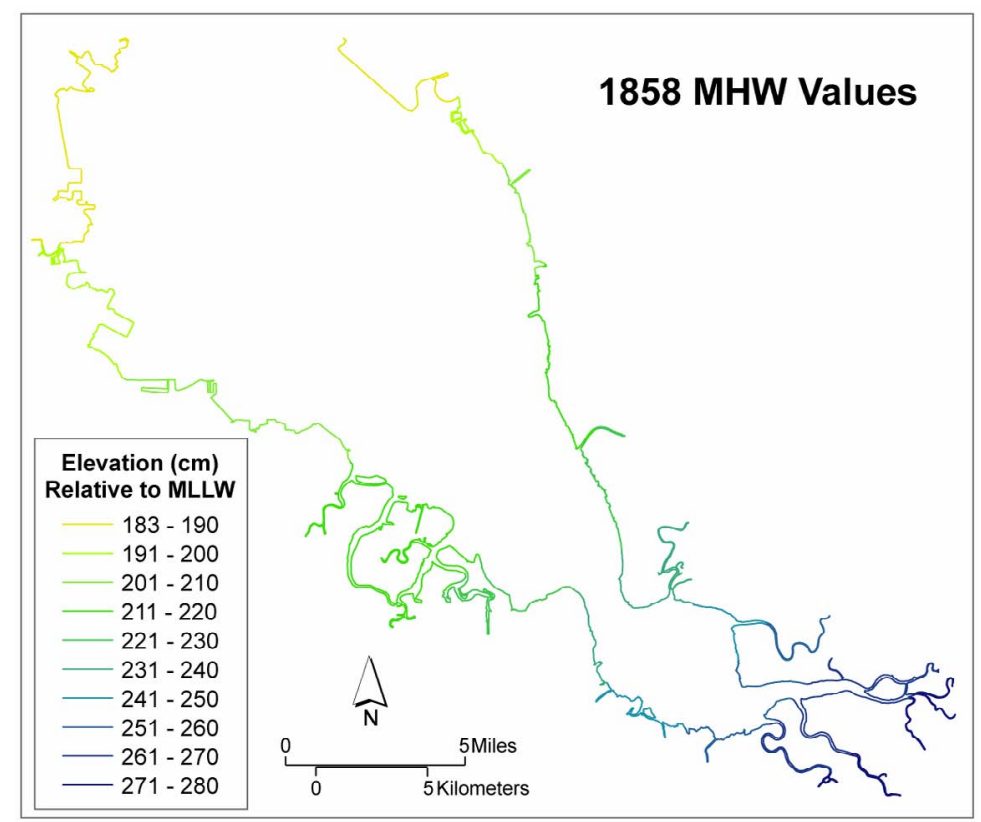

Figure 8. Mean High Water values assigned to shorelines.

\section{Surface Modeling}

Once the data has been combined into a GIS, we used ArcInfo's TopoGrid module to generate a continuous surface representation ( $50 \mathrm{~m}$ horizontal resolution) of each bathymetric survey. TopoGrid is a gridding algorithm designed to utilize both sounding and contour data to generate a hydrologically correct Digital Elevation Model (DEM). TopoGrid uses an iterative finite difference interpolation technique in which the contours are initially used to build a generalized drainage model that is further refined using both soundings and contour values to determine elevation values at each cell. Each historical bathymetric survey is defined by over 160,000 grid cells. Bathymetry in tributary channels less than $150 \mathrm{~m}$ wide were excluded because they could not be accurately modeled at a resolution of $50 \mathrm{~m}$.

\section{Error Checking}

Error checking is an iterative procedure that took place at various stages of data processing. An initial round of error checking was conducted once all of the data has been combined into a GIS through visual inspection in ArcMap. Point data were classified by elevation in feet. Class boundaries are chosen to correspond with the contour interval ( 0 to 6,7 to 12,13 to 18 , etc.). Contrasting colors were then used to shade the point data. Large errors (decimal point off, attribute typos, etc.) tend to stand out and can be detected in this way. Contours were also checked for agreement with the point data (e.g., all the red points should be on one side of the contour, all the blue points on the other) (Fig. 9). 


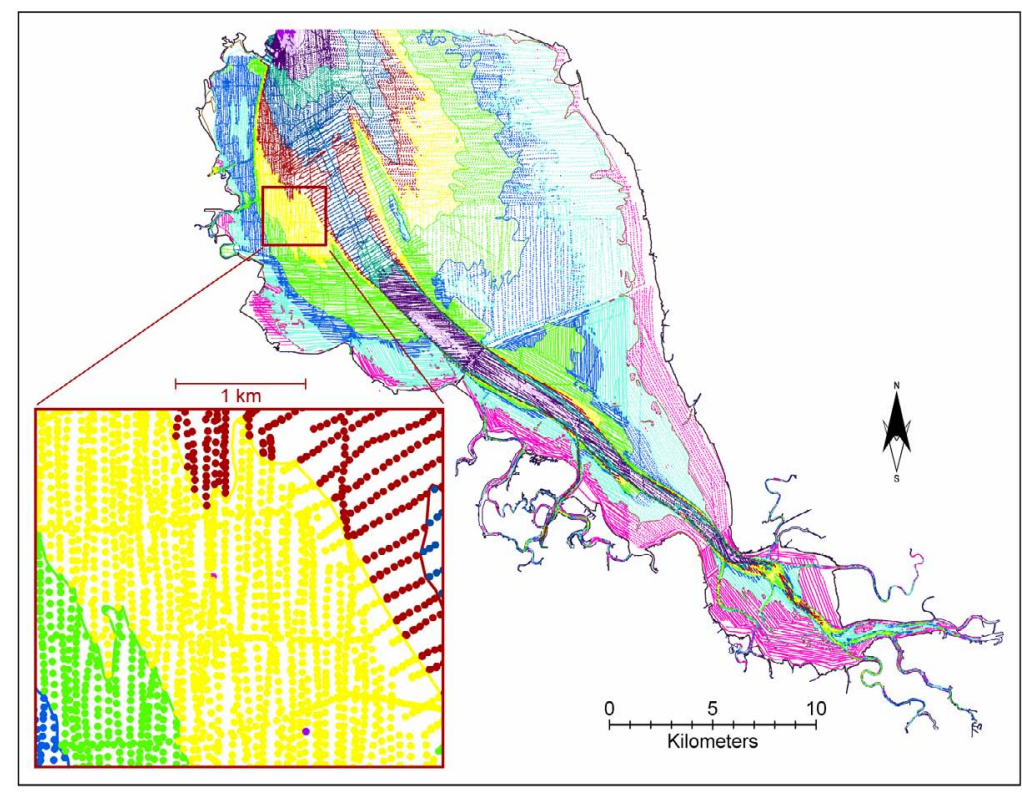

Figure 9. Sample of visual error checking technique applied to both soundings and contours.

A secondary visual inspection was performed upon the first round of grid production. The bathymetric grid from each time series was hill-shaded to accentuate any abnormalities in the morphology of the bay floor. For example, erroneous soundings may appear as abnormal pits or mounds relative to the surrounding data. Erroneous soundings were either corrected or removed from the input data.

Errors were also evaluated statistically by comparing the value of each individual sounding to the cell value of the bathymetric grid at that specific location. The difference between soundings and corresponding grid cells is useful in identifying areas of error and also serves as a means for quantifying how well the surface represents the original point data (Table 6). The greatest differences in individual soundings and cell values occurred along the steep slope of the main channel where large gradients in bathymetry could not be resolved within a single $50 \mathrm{~m}$ grid cell.

Table 6. Table of grid bias, representing difference between sounding values and corresponding grid cells. This serves as a proxy for how well the surface represents the original sounding data.

\begin{tabular}{|c|c|c|c|c|c|c|c|c|c|}
\hline$\overline{\text { Year }}$ & Frequency & \multicolumn{2}{|c|}{ Maximum } & \multicolumn{2}{|c|}{ Minimum } & \multicolumn{2}{|c|}{ Mean } & \multicolumn{2}{|c|}{ "Std. Deviation } \\
\hline & & $(\mathbf{c m})$ & $(\mathrm{ft})$ & $(\mathbf{c m})$ & $(\mathrm{ft})$ & $(\mathbf{c m})$ & $(\mathbf{f t})$ & $(\mathrm{cm})$ & $(\mathrm{ft})$ \\
\hline 1858 & 17986 & 542 & 1778 & -707 & -2320 & -86 & -0.28 & 589 & 193 \\
\hline 1898 & 87,273 & 617 & 20.24 & -888 & -29.13 & -1.6 & -0.05 & 39.2 & 1.29 \\
\hline 1931 & 76,678 & 687 & 22.54 & -890 & -29.20 & -1.9 & -0.06 & 48.2 & 1.58 \\
\hline 1956 & 77,397 & 654 & 21.46 & -864 & -28.35 & -1.7 & -0.06 & 48.2 & 1.58 \\
\hline 1983 & 128,467 & 861 & 28.25 & -748 & -24.54 & -0.3 & -0.01 & 48.8 & 1.60 \\
\hline
\end{tabular}

\section{Sediment Volume Change Analysis}

Prior to conducting analyses of sediment deposition and erosion, some adjustments were made to the bathymetric grids. A vertical datum adjustment was applied to bring all of the surveys to a common vertical datum. It was also necessary to account for subsidence of the bay floor that occurred from 1934 to 1967 . Once these adjustments were made, the corrected grids were differenced to reveal deposition and erosion that occurred during consecutive surveys. 


\section{Vertical Datum Adjustment}

The USCGS and NOS hydrographic surveys are relative to the MLLW vertical datum. MLLW is the average of the lower low water height of each tidal day observed at a given tidal station over the National Tidal Datum Epoch, a specific 19-year cycle (18.6 year tidal epoch rounded to a full year to minimize bias from seasonal variation). The MLLW tidal datum, therefore, varies depending upon the 19-year cycle used for measurement. Prior to generating sediment volume change calculations, all of the bathymetric grids were adjusted to a common vertical datum to account for changing survey datums accompanying fluctuations in sea level over the 125-year span of the surveys.

During the temporal span of this study (1856-1983), five tidal datum epochs were used for the tide station at San Francisco (Golden Gate). The 19-year cycle from 1960-78 was used to calculate MLLW values for the most recent (1983) hydrographic surveys in South San Francisco Bay. Earlier epochs used for San Francisco include: 1858-73, 1878-96, 1898-1916, 1924-42, and 1941-59. The epoch used as the vertical datum reference for hydrographic surveys was presumed to be the 19-year cycle most recently preceding the date of the survey with the exception of the 1850's surveys for which there was no previously established tidal epoch.

Assuming no change in the bathymetry, an increase in the height of the tidal datum between surveys would result in a sounding from the later survey appearing deeper than a sounding at the same location from the earlier survey. An adjustment was derived to bring the historical surfaces to the same vertical datum used for the 1983 surface by differencing the staff reading for MLLW corresponding to a historical survey from the staff reading for MLLW during the 1960-78 epoch (Table 7). This method could not be used to adjust the 1858 surface because there was not a 19year period of records at the time the survey was collected. We were unable to find any documentation stating how these early surveys were referenced to MLLW. We have assumed these surveys were referenced to MLLW over the time in which they were collected. Using monthly MLLW values for Fort Point tidal station, we averaged the MLLW values for January, February, and March of 1857 and 1858 which represent the months in which these surveys were collected.

Table 7. Vertical Datum Adjustments.

\begin{tabular}{|c|c|c|c|c|c|}
\hline \multirow[t]{2}{*}{ Survey Year } & \multirow[t]{2}{*}{ Presumed Epoch } & \multicolumn{2}{|c|}{ MLLW on staff } & \multicolumn{2}{|c|}{$\begin{array}{c}\text { Diff. from MLLW } \\
1960-78\end{array}$} \\
\hline & & $(\mathrm{m})$ & $(\mathrm{ft})$ & (m) & $(\mathrm{ft})$ \\
\hline${ }^{1} 1858$ & N/A & 1.62 & 5.31 & 0.14 & 0.46 \\
\hline 1898 & $1878-96$ & 1.72 & 5.65 & 0.04 & 0.12 \\
\hline 1931 & $1898-16$ & 1.67 & 5.49 & 0.09 & 0.28 \\
\hline 1956 & $1924-42$ & 1.71 & 5.61 & 0.05 & 0.16 \\
\hline 1983 & $1960-78$ & 1.76 & 5.77 & --- & --- \\
\hline
\end{tabular}

${ }^{1} 19$ year tidal epoch not available for 1858 adjustment. MLLW value calculated by averaging monthly MLLW values over the time in which the surveys were collected.

\section{Subsidence Correction}

In calculating net sediment volume change, it was necessary to account for land subsidence that occurred within the southern extent of South San Francisco Bay as a result of excessive ground water withdrawal from 1934 to 1967 . Without correcting for subsidence, our grids of deposition and erosion would erroneously overestimate erosion during these time periods. The degree and spatial extent of subsidence was documented in Poland and Ireland (1988). The influence of subsidence extended from the Santa Clara Valley as far north as Ravenswood Point and ranged

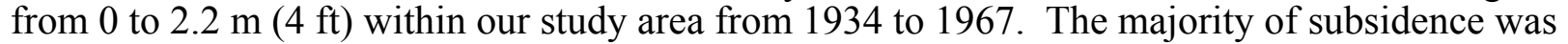
concentrated in San Jose, approximately $16.1 \mathrm{~km}(10 \mathrm{mi})$ south of our study area where subsidence

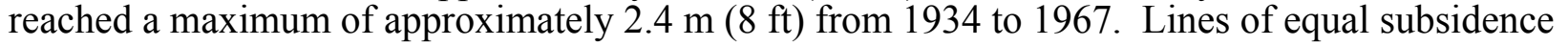


were digitized from two maps published by Poland and Ireland (1988); one depicting subsidence that occurred from 1934 to 1960 and a second map displaying subsidence from 1960 to 1967. These maps were used to generate a continuous surface of subsidence for each of the two time periods. Assuming linear rates for each map period, the proportion of subsidence that occurred from 1934 to 1956 was applied to the 1931 to 1956 grid of deposition and erosion, while the remaining proportion was applied to the 1956 to 1983 surface (Fig. 10). This subsidence correction accounts for approximately $16 \times 10^{6} \mathrm{~m}^{3}$ or $24 \%$ of the net sediment volume change from 1931 to 1956 and $9 \times 10^{6} \mathrm{~m}^{3}$ or $13 \%$ of the net change from 1956 to 1983 .

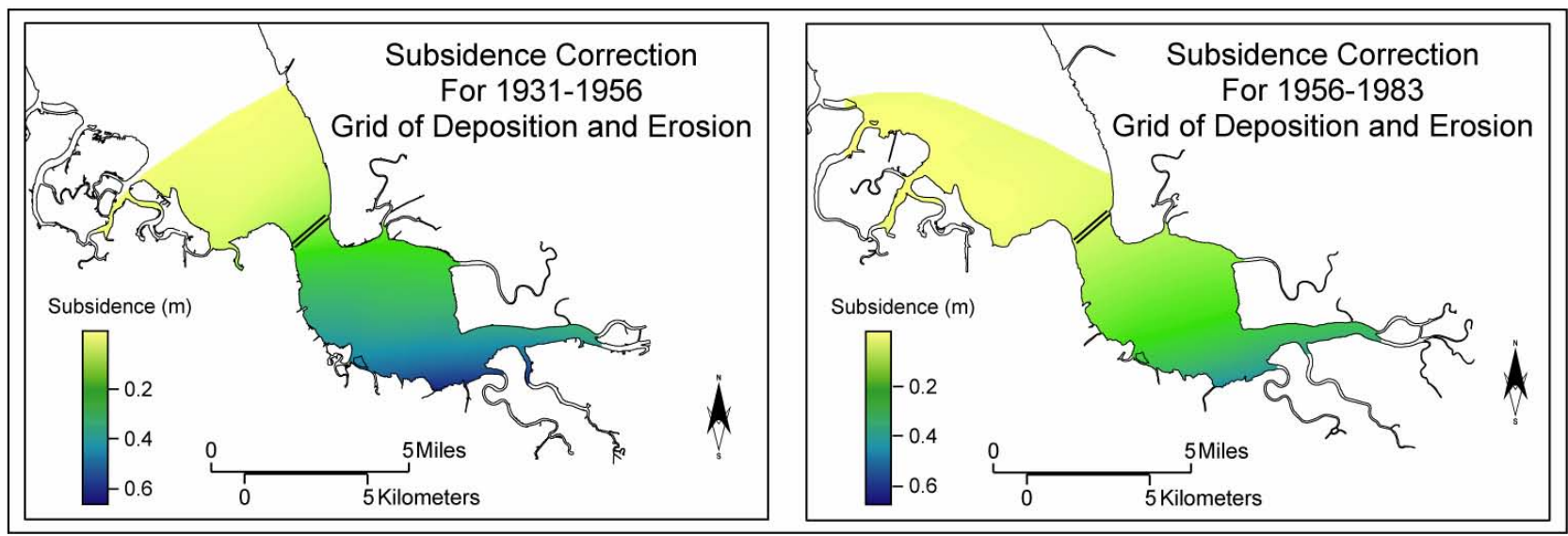

Figure 10. Subsidence corrections applied to 1931 to 1956 and 1956 to 1983 grids of deposition and erosion.

Santa Clara Valley residents began to realize that the land was subsiding in the early $1900 \mathrm{~s}$ and some limited leveling benchmarks were surveyed by the National Geodetic Survey beginning in 1912. It wasn't until 1933 that an extensive network was laid out to determine the extent, magnitude and rate of subsidence (Poland and Ireland, 1988). Since there were not reliable measurements of the subsidence that occurred prior to 1934 (although presumed to be minor), we were unable to account for subsidence that occurred during this time. As a result, it is possible that we have slightly underestimated deposition that occurred in the southernmost extent of the bay from 1898 to 1931. Significant subsidence has not occurred within the area since about 1969 (Ingebritsen and Jones, 1999).

\section{Sediment Volume Change Calculations}

Once all of the adjustments have been made, maps of deposition and erosion were generated by differencing the corrected bathymetric grids. To improve comparability of sediment volumes for all surveys, maps of deposition and erosion were limited to only calculate values in tributary channels that contained bathymetric data for all five time periods. Multiplying the grids of deposition and erosion by surface area on a cell-by-cell basis resulted in volumetric measurements of sediment change.

\section{Summary of Observations}

While the primary focus of our study is bathymetry and the deposition and erosion of sediment, we've also included an estimate of change in the area of tidal marsh. Marsh boundaries were used solely for display purposes and approximations of total marsh area. Changes in marsh are not accounted for in sediment volume change calculations. 


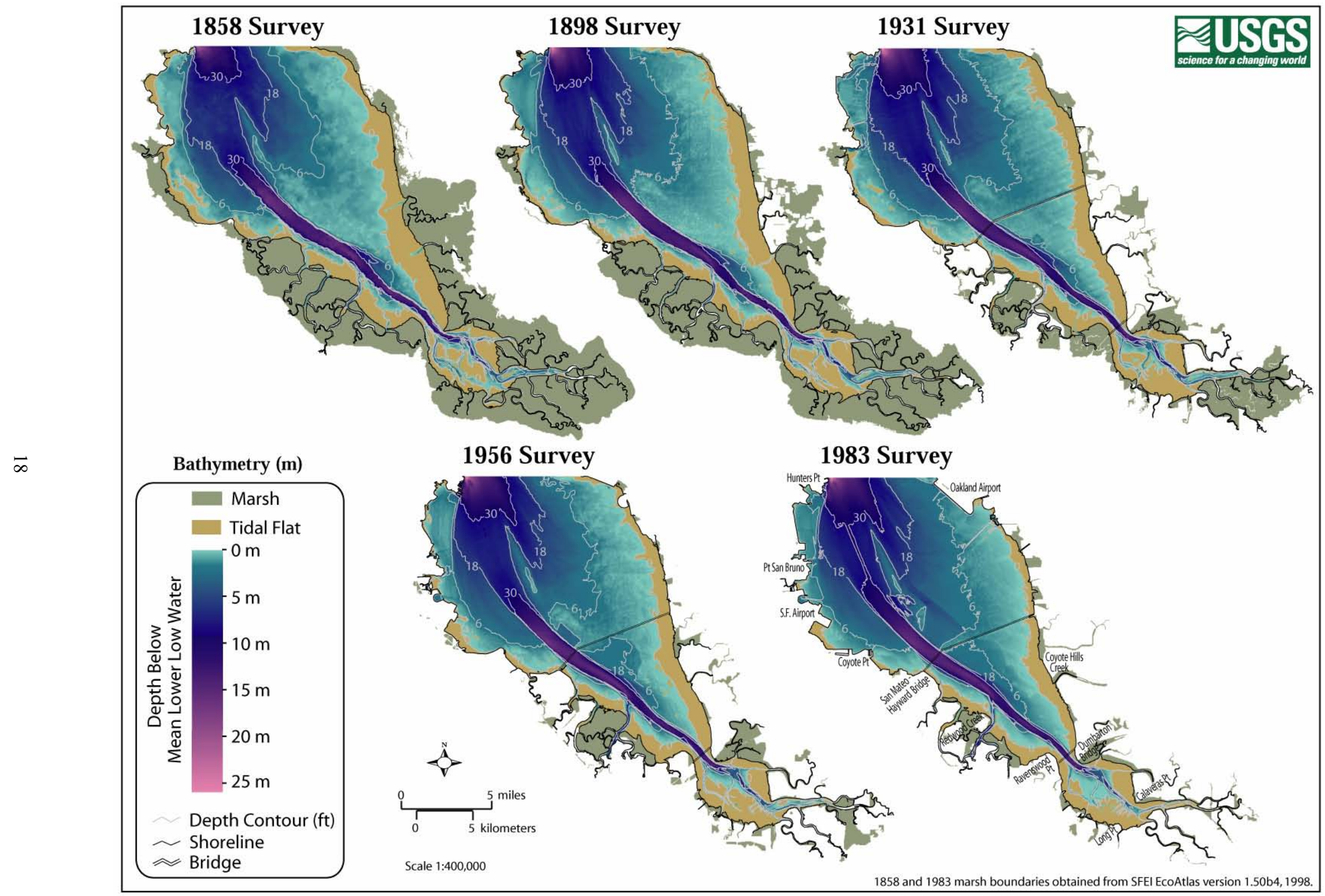

Figure 11. Preliminary bathymetry maps of South San Francsico Bay from 1858 to 1983. 


\section{Bay Characteristics}

Examination of the bathymetric surfaces revealed interesting characteristics of South San Francisco Bay's underwater topography. A main channel, approximately one kilometer in width, runs longitudinally down the majority of the bay. The average depth of the channel is approximately $11 \mathrm{~m}$ and is flanked on either side by expansive shoals. The morphology of the bay varies from north to south and, with the exception of the area south of the Dumbarton bridge, has remained relatively stable from 1858 to 1983 (Fig. 12).

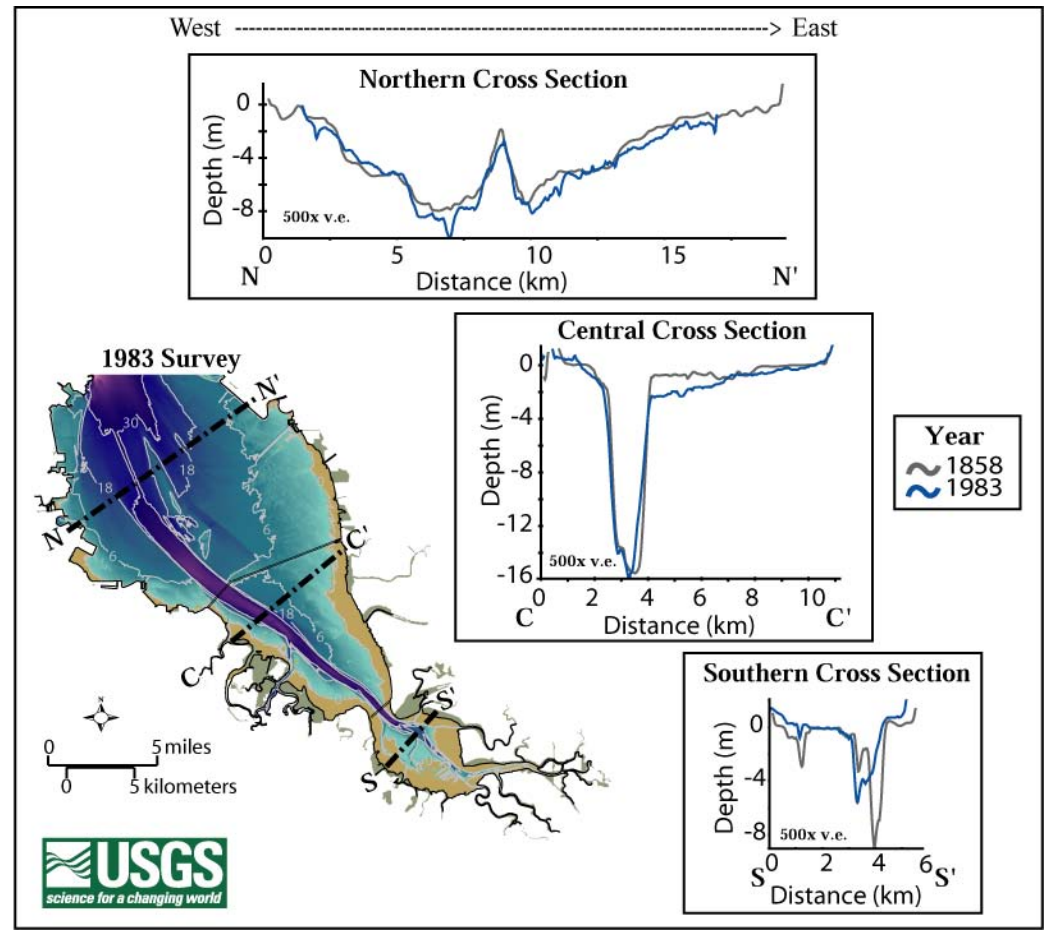

Figure 12. Preliminary cross section profiles of the bay floor in 1858 and 1983.

South San Francisco Bay is a relatively shallow estuary. While the average depth for all of San Francisco Bay is $6 \mathrm{~m}$ at MLLW (Conomos, 1979), the average depth within our study area is approximately $3 \mathrm{~m}$ at MLLW (this value is strongly dependent upon where our northern boundary was placed). Only $25 \%$ of the bay is deeper than $5 \mathrm{~m}$ at MLLW; the maximum depth is approximately $26 \mathrm{~m}$ (near Hunter's Point; see Fig. 1). The 1983 surface area of the bay is approximately $410 \mathrm{~km}^{2}$, down from approximately $430 \mathrm{~km}^{2}$ in 1858 .

Table 8. 1983 South San Francisco bay characteristics, values relative to MLLW.

\begin{tabular}{||l|c||}
\hline \multicolumn{1}{|c|}{ statistic } & value \\
\hline & \\
\hline Average Depth & $3 \mathrm{~m}$ \\
\hline Median Depth & $2 \mathrm{~m}$ \\
\hline Surface Area & $410 \mathrm{~km}^{2}$ \\
\hline Tidal Flat Area & $58 \mathrm{~km}^{2}$ \\
\hline Navigable Area (deeper than 30ft) & $43 \mathrm{~km}^{2}$ \\
\hline Shallow Area (less than 6ft deep) & $194 \mathrm{~km}^{2}$ \\
\hline
\end{tabular}




\section{Area of Marsh}

One of the striking features we observed in our time series of South San Francisco Bay is the dramatic loss of tidal marsh throughout the years (Fig 13). From 1858 to 1983 more than 80\% of tidal marshes were converted to salt ponds, agricultural fields, and urban areas (the 1858 and 1983 marsh boundaries were obtained from the SFEI EcoAtlas, 1998). The California State Coastal Conservancy, the U.S. Fish and Wildlife Service and the California Department of Fish and Game are currently developing plans to restore $61 \mathrm{~km}^{2}\left(24 \mathrm{mi}^{2}\right)$ of salt pond to mixed wetland habitat (see http://www.southbayrestoration.org/index.html for restoration details). If all $61 \mathrm{~km}^{2}$ were to be successfully restored to tidal marsh, this would return the marsh to approximately $40 \%$ of its 1858 extent.

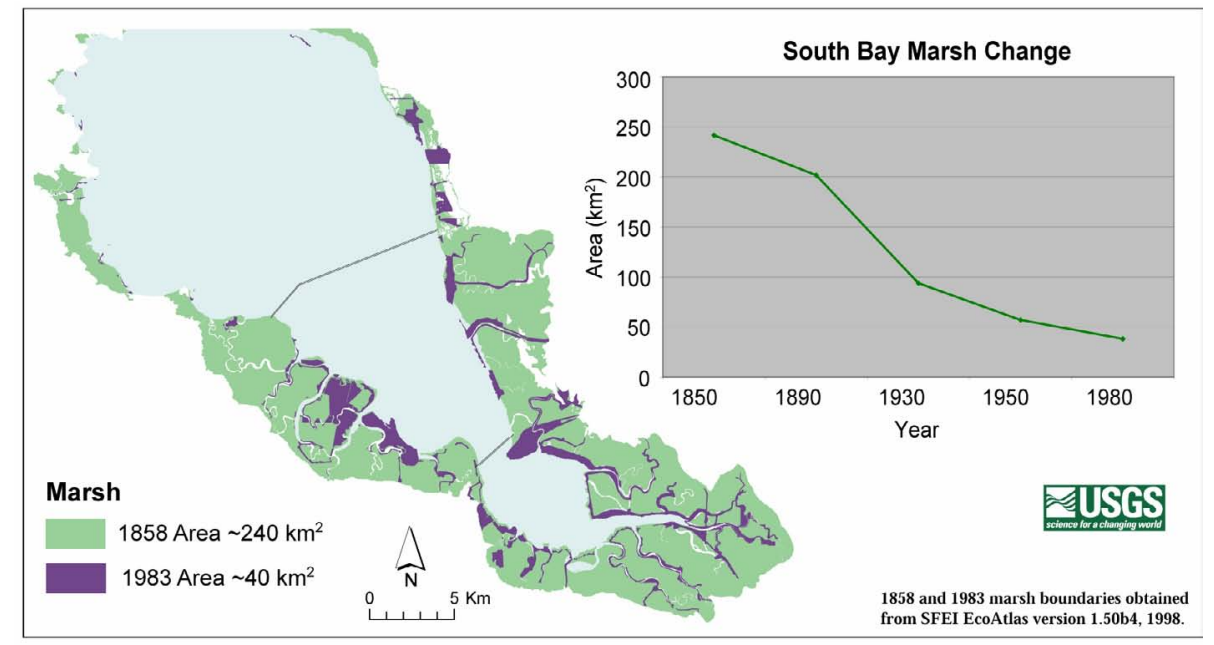

Figure 13. Preliminary change in area of marsh in South San Francisco Bay from 1858 to 1983.

\section{Area of Tidal Flat}

Tidal flat area has decreased from $92 \times 10^{6} \mathrm{~m}^{3}$ in 1858 , to $58 \times 10^{6} \mathrm{~m}^{3}$ in 1983 , representing a $40 \%$ decrease in tidal flat area (Fig 14). The majority of this decline has occurred on the eastern shore, north of the Dumbarton Bridge (Fig. 1).

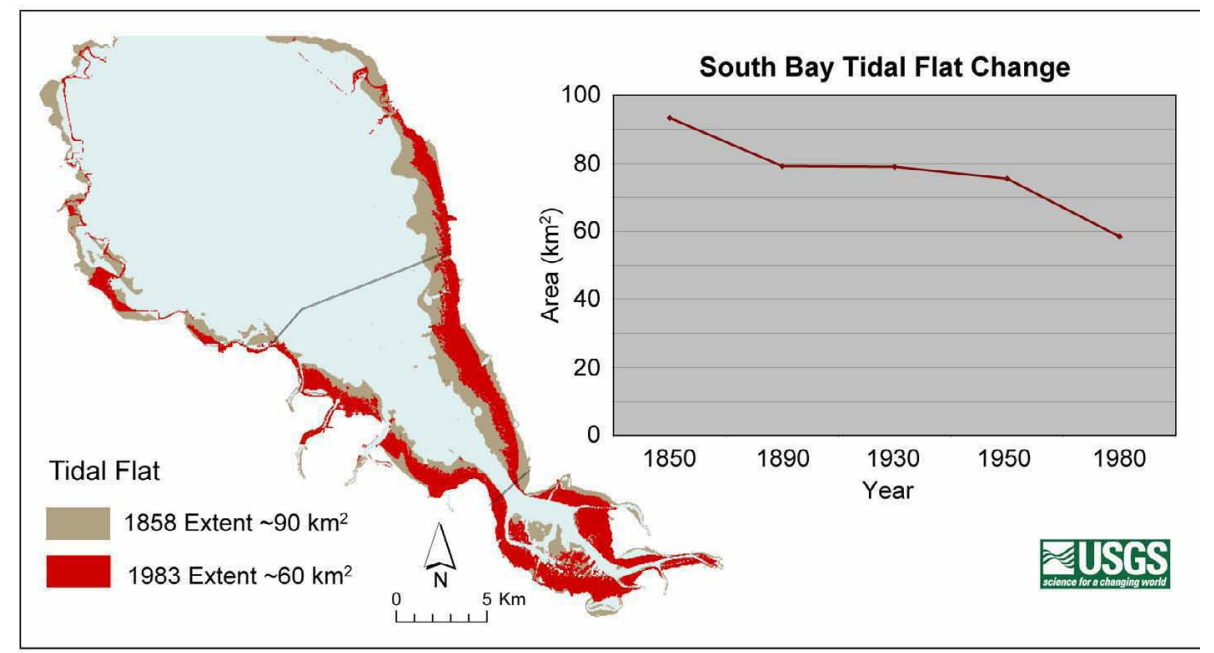

Figure 14. Preliminary change in tidal flat area in South San Francisco Bay from 1858 to 1983. 


\section{Net Sediment Volume Change}

South San Francisco Bay has experienced a net loss of sediment from 1858 to 1983; however within this timeframe there have been periods of both deposition and erosion. From 1858 to 1898 the bay experienced a small amount of deposition, approximately $7 \times 10^{6} \mathrm{~m}^{3}$, followed by an erosional period of $91 \times 10^{6} \mathrm{~m}^{3}$ from 1898 to 1931 . From 1931 to 1956 the system reversed, and $66 \times 10^{6} \mathrm{~m}^{3}$ of sediment was deposited. From 1956 to 1983 an erosion of approximately $71 \times 10^{6}$ $\mathrm{m}^{3}$ was measured. 


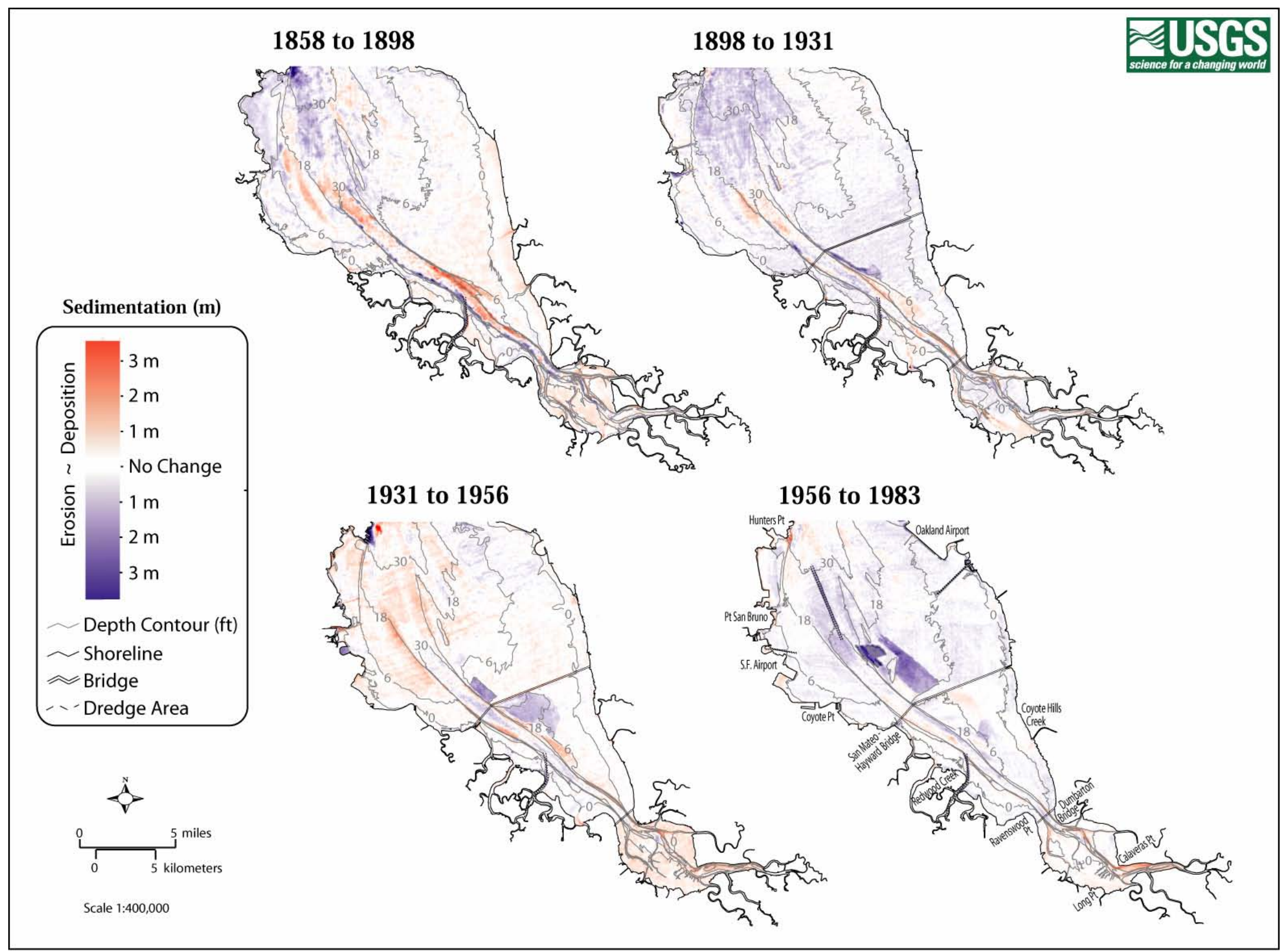

Figure 15. Preliminary maps of sediment deposition and erosion in South San Francsico Bay from 1858 to 1983. 
When interpreting calculations of deposition and erosion, it is important to consider the impact that dredging has on the system. Many of the major harbors throughout the bay began routine dredging of sediment as early as the 1800s. Large areas in the bay (borrow pits) were also dredged for material used in bay fill and cement production. We identified borrow pits as areas with anomalous erosion volumes and patterns. The location of the four borrow pits shown in Figure 16 were confirmed by bay area scientists and managers. We can use our grids to estimate the volume of sediment removed by dredging. However, without accurate records of dredging activities (i.e., when dredging occurred, how much sediment was removed, and where sediment was deposited) it is difficult to separate the sediment volume change associated with anthropogenic activities from those associated with natural changes in deposition and erosion. Unless all of the dredging occurred just prior to the collection of the hydrographic survey (allowing no time for sediment to be redeposited at the site), the volumes shown in Figure 16 are minimum estimates. The relative proportion of sediment loss accounted for in these four borrow pits is shown in Figure 17.

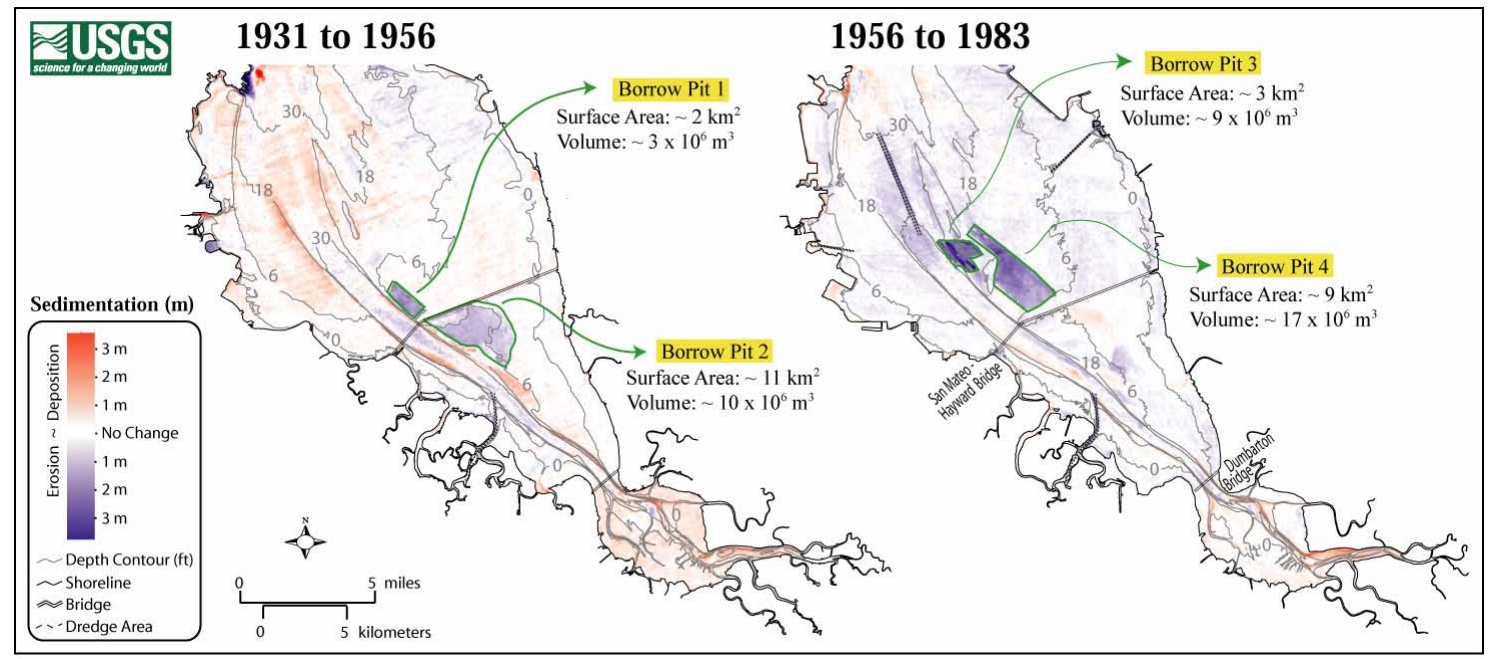

Figure 16. Location of sediment borrow pits seen in preliminary 1931 to 1956 and 1956 to 1983 maps of deposition and erosion. Approximate surface areas and volumes represent those at the time in which the hydrographic surveys were conducted (not necessarily equal to the areas and volumes of sediment originally removed).

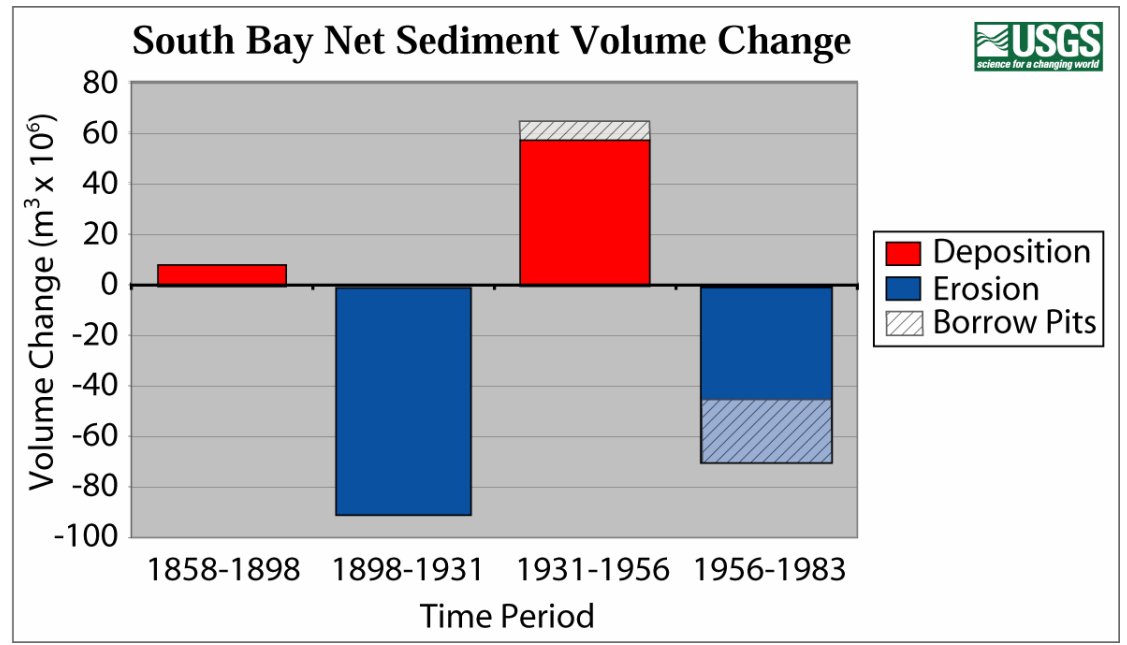

Figure 17. Preliminary South San Francisco Bay net sediment volume change calculations. Our minimum estimates for the volume of sediment removed from borrow pits from 1931 to 1956 and from 1956 to 1983 are indicated by a hachured pattern. 
We have calculated net sediment volume rates in four regions to determine how patterns of deposition and erosion vary spatially within the bay. Region 4, the area south of the Dumbarton Bridge, is the only region which has remained depositional over time (Fig. 18). The overall similarity in trends of all four regions, with an offset, is a signature of sediment redistribution from north to south within the bay in conjunction with a changing sediment supply (Jaffe, et al. submitted).

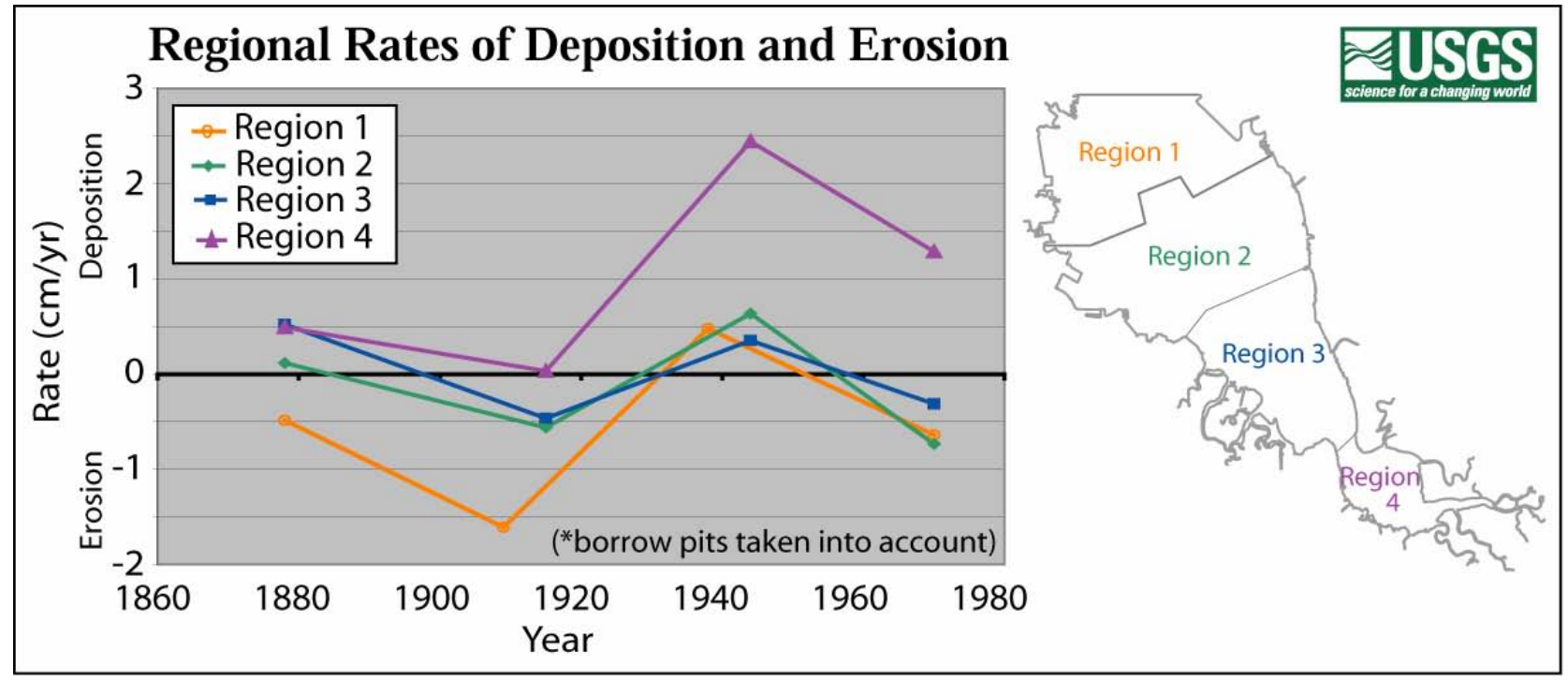

Figure 18. Preliminary rates of net deposition and erosion, by region (with borrow pits taken into account).

\section{Future Work}

While this study has provided us with a preliminary look at the long-term patterns of sediment deposition and erosion within South San Francisco Bay, we intend to take a more in-depth look into what implications this may have for both physical and biological processes. As previously mentioned, we plan to improve our surface models by updating features such as shoreline values, 1858 tidal flat soundings, and nearshore morphology as the necessary data becomes available. A LIght Detection And Ranging (LIDAR) survey of South San Francisco Bay is scheduled for May of 2004 enabling us to take a closer look at tidal flat geomorphology and document how the tidal flats have changed from 1983 to present. In addition, we would like to conduct a more detailed analysis of the relationship between marsh and tidal flat change and what implications that may have for marsh restoration. Errors in sediment volume change calculations are dependent upon sounding accuracies, uncertainties in determining the relationship of MLLW datums for different surveys, and from grid representations or the interpolation of the original point data (Table 6). These errors will be quantified and a confidence envelope applied to our sediment volume change calculations. We will further investigate what led to the large deposition noted in the $1920 / 31$ to 1956 survey. We intend to continue this research by conducting a similar time series analysis of Central San Francisco Bay which may improve our understanding of trends in sediment deposition during this anomalous period. The completion of Central Bay analyses will allow us to improve estimates of a bay-wide sediment budget. 


\section{Acknowledgements}

This research was supported by the U.S. Geological Survey Priority Ecosystem Study of San Francisco Bay and the San Francisco Bay Regional Water Quality Control Board. This report was improved by reviews from Cheryl Hapke and Ann Gibbs.

\section{References}

Cappiella, K., Malzone, C., Smith, R., and Jaffe, B., 1999, Sedimentation and Bathymetry Changes in Suisun Bay: 1867-1900: U.S. Geological Survey Open-File Report 99-563. [URL:

http://geopubs.wr.usgs.gov/open-file/of99-563]

Conomos, T.J., 1979, Properties and Circulation of San Francisco Bay Waters: in T.J. Conomos, Eds., San Francisco Bay the Urbanized Estuary, Pacific Division AAAS, San Francisco, p. 47-84.

Dedrick, K.G., 1983, Use of Early Hydrogrpahic Surveys in Studies of California Estuaries. Coastal Zone '83, Vol III., p. 2294-2316.

Ingebritsen, S.E., and Jones, D.R., 1999, Santa Clara Valley, California: A case of arrested subsidence: in Galloway, D., Jones, D.R., and Ingebritsen, S.E., Eds., Land Subsidence in the United States, U.S. Geological Survey Circular 1182, p. 15-22.

Jaffe. B.E., Smtih, R.E., Torresan, L., 1998, Sedimentation and Bathymetric Change in San Pablo Bay: 1856-1983: U.S. Geological Survey Open File Report 98-759. [URL:

http://geopubs.wr.usgs.gov/open-file/of98-759]

Jaffe B.E., Smith, R.E., Foxgrover, A.C., submitted, Anthropogenic Influence on Sedimentation and Intertidal Mudflat Change in San Pablo Bay, California: 1856 to 1983: Estuarine, Coastal and Shelf Science.

Mitchell, H.C., 1936, First and Second Order Triangulation in California (1927 Datum), Special Publication No. 202, U.S. Coast and Geodetic Survey, Washington.

National Geodetic Survey NOAA Shoreline Data Explorer, [URL: http://www.ngs.noaa.gov/newsys_ims/shoreline/index.cfm]

National Geophysical Data Center, GEOphyscial Data System for Hydrographic Survey Data, 1996, Version 3.3, CD-ROM Set.

Poland, J.F., and Ireland, R.L. 1988, Land Subsidence in the Santa Clara Valley, California, as of 1982: U.S. Geological Survey Professional Paper 497-F, 61 p.

San Francisco Estuary Institute EcoAtlas, 1998, Version 1.50b4, Compact Disc.

United States Geological Survey San Francisco Bay Bathymetry Web Site [URL: http://sfbay.wr.usgs.gov/access/Bathy/grids.html] 